Wells, S.A. and LaLiberte, D. (1998) "Winter temperature gradients in circular clarifiers," Water Environment Research, Volume 70, Number 7, pp. 1274-1279.

\title{
Winter Temperature Gradients in Circular Clarifiers
}

\author{
Scott A. Wells \\ David M. LaLiberte
}

\begin{abstract}
To understand the effect of temperature induced density currents on circular clarifiers, a field study was performed on three uncovered circular tanks in Oregon during periods of low flow and high surface cooling. Temperatures were measured as a function of radial position and tank depth. Meteorological parameters were also measured in order to compute the surface heat flux from the water surface. The water temperatures in the tank were often 20 to $30^{\circ} \mathrm{C}$ warmer than the equilibrium temperature.
\end{abstract}

These studies showed that density currents and unstable temperature gradients were common. Surface temperatures were often about $1^{\circ} \mathrm{C}$ cooler than bottom temperatures. The momentum and suspended solids of the inflow caused a density current that moved along the clarifier bottom and then rose near the middle of the tank. In the winter, this density current rose as a result of the decrease of initial momentum of the inflow, the buoyancy of the inflow after suspended solids had settled, and the geometry of the tank. Also, vertical velocities induced by surface cooling were two orders of magnitude greater than the overflow rate. This suggests that particles could be kept in suspension by convective currents.

\section{Key Words}

sedimentation, clarifier, temperature, suspended solids, overflow rate, density currents, convective cooling, heat loss

\section{Introduction}

Design of sedimentation tanks for water and wastewater treatment processes are often based on the surface overflow rate $(Q / A$, where $Q$ is the flow rate and $A$ is the clarifier surface area) of the tank. This design variable is predicated on the assumption of uniform unidirectional flow through the tank. Dick (1982), though, showed that many full-scale sedimentation tanks do not follow ideal flow behavior because suspended solids removal in a clarifier was often not a function of the overflow rate. Because of uncertainties in the hydrodynamics of clarifiers, designers typically use safety factors to account for this nonideal flow behavior (Abdel-Gawad and McCorquodale, 1984). 
Non-ideal flow behavior can be the result of the following (DeVantier and Larock, 1987; Tay and Heinke, 1983; Wells, 1990):

1. inlet and outlet geometry

2. inflow jet turbulence

3. dead zones in the tank

4. resuspension of settled solids

5. density currents caused by suspended solids and temperature differentials within the tank.

Non-ideal flow behavior as a result of temperature and suspended solids differentials in uncovered, circular tanks was studied at three locations in Oregon. The magnitude of vertical velocities induced by surface heat losses was computed and compared with tank overflow rates. Tank overflow rates provided an estimate of the order of magnitude of the critical settling velocity of a particle that could be captured in the tank (Dick, 1982).

\section{Experimental Methods}

Experiments were conducted in Oregon during the winter at wastewater treatment plants in Lake Oswego and Bend. Primary and secondary sedimentation tanks were evaluated at the Bend wastewater treatment plant. The circular tank at the Lake Oswego treatment plant was functioning as a chlorine contact chamber rather than its intended design as a secondary clarifier.

In order to examine the effects of surface cooling, study periods were chosen coinciding with winter weather conditions when surface heat losses would be significant. These conditions were most significant during the early morning hours when plant flow rates were low and winter cooling was greatest.

All the tanks had a centerwell feed, an inlet baffle and a perimeter effluent weir. Figure 1 shows a schematic of the circular tanks, and Table 1 shows physical characteristics of those tanks. Table 2 shows the five study periods and the average flow rates, overflow rates, and detention times for each period.

In order to measure the temperature distributions in these tanks, thermistors at five varying depths were attached to poles $3.3 \mathrm{~m}$ in length at three radial positions in the tank. Each thermistor was attached to a computer data logger that recorded temperature continuously during the study periods. The study period for the Bend primary and secondary sedimentation tanks was between 2 and 3 hours. At the Bend treatment plant for both the primary and secondary clarifiers, the thermistors had to be removed and reinstalled into the tank every half hour because of the skimmer and rake arm rotation. Because the Lake Oswego plant had no skimmer or rake arms, the study period was continuous over a period of 4 days. The thermistors were calibrated in the laboratory with a typical error of $\pm 0.2^{\circ} \mathrm{C}$. Figure 2 shows approximate locations of the thermistor array in the circular tank. 
Table 1 Clarifier tank data (variables named below are referenced in Figure 1).

\begin{tabular}{|l|l|l|l|}
\hline Tank parameter & Chlorine contact & Primary clarifier & Secondary clarifier \\
\hline \hline Treatment plant & Lake Oswego & Bend & Bend \\
\hline Tank radius $(\mathrm{R}), \mathrm{m}(\mathrm{ft})$ & $11.4(37.5)$ & $9.9(32.5)$ & $12.2(40.0)$ \\
\hline $\begin{array}{l}\text { Tank inlet baffle radius } \\
\left(\mathrm{r}_{\mathrm{b}}\right), \mathrm{m}(\mathrm{ft})\end{array}$ & $1.2(4.0)$ & $2.1(7.0)$ & $2.1(7.0)$ \\
\hline $\begin{array}{l}\text { Depth of inlet baffle, } \mathrm{m} \\
(\mathrm{ft})\end{array}$ & $1.8(6.0)$ & $2.4(8.0)$ & $2.4(8.0)$ \\
\hline $\begin{array}{l}\text { Maximum depth at } \\
\text { center-well }\left(\mathrm{H}_{\max }\right), \mathrm{m}(\mathrm{ft})\end{array}$ & $3.0(9.9)$ & $3.5(11.5)$ & $4.6(15.0)$ \\
\hline $\begin{array}{l}\text { Minimum depth at tank } \\
\text { edge }\left(\mathrm{H}_{\min }\right), \mathrm{m}(\mathrm{ft})\end{array}$ & $2.7(8.9)$ & $3.2(10.5)$ & $3.5(11.5)$ \\
\hline Bottom slope & $1: 40$ & $1: 32$ & $1: 12$ \\
\hline Area, surface, $\mathrm{m}^{2}\left(\mathrm{ft}^{2}\right)$ & $410(4420)$ & $308(3320)$ & $467(5027)$ \\
\hline Volume, $\mathrm{m}^{3}(\mathrm{MG})$ & $1175(0.31)$ & $1035(0.27)$ & $1900(0.5)$ \\
\hline
\end{tabular}


Table 2. Physical and hydraulic data during study periods.

\begin{tabular}{|l|l|l|l|l|l|}
\hline Parameter & $\begin{array}{l}\text { Oswego } \\
\text { chlorine } \\
\text { contact, } \\
2 / 3 / 89- \\
2 / 7 / 89\end{array}$ & $\begin{array}{l}\text { Bend primary } \\
\text { clarifier, } \\
1 / 21 / 89,5 \\
\text { am }-8 \mathrm{am}\end{array}$ & $\begin{array}{l}\text { Bend } \\
\text { secondary } \\
\text { clarifier, } \\
1 / 22 / 89,11 \mathrm{pm} \\
-3 \mathrm{am}\end{array}$ & $\begin{array}{l}\text { Bend primary } \\
\text { clarifier, } \\
3 / 4 / 89,2 \mathrm{am} \\
-6 \mathrm{am}\end{array}$ & $\begin{array}{l}\text { Bend } \\
\text { secondary } \\
\text { clarifier, } \\
3 / 5 / 89,2 \mathrm{am} \\
-6: 30 \mathrm{am}\end{array}$ \\
\hline \hline $\begin{array}{l}\text { Average flow rate, } \\
\mathrm{m}^{3} / \mathrm{s} \text { (MGD) }\end{array}$ & $0.1(2.4)$ & $0.03(0.6)$ & $0.04(0.9)$ & $0.06(1.3)$ & $0.03(0.7)$ \\
\hline $\begin{array}{l}\text { Overflow rate, } \\
\mathrm{m}^{3} / \mathrm{m}^{2} / \mathrm{day} \\
\text { (gal/ft } / \text { day) }\end{array}$ & $\begin{array}{l}21.7 \\
(533)\end{array}$ & $7.4(182)$ & $6.9(169)$ & $15.3(375)$ & $5.5(135)$ \\
\hline $\begin{array}{l}\text { Sludge pumping } \\
\text { rate from clarifier }\end{array}$ & none & $\begin{array}{l}\text { Pump cycle 3 } \\
\text { min every 2 } \\
\text { hrs, 42 } \\
\mathrm{m}^{3} / \mathrm{day} \\
(11,000 \\
\text { gal/day) }\end{array}$ & $\begin{array}{l}40 \% \text { return } \\
\text { activated } \\
\text { sludge rate }\end{array}$ & $\begin{array}{l}\text { Pump cycle 3 } \\
\text { min every 2 } \\
\text { hrs, 42 } \\
\mathrm{m}^{3} / \mathrm{day} \\
(11,000 \\
\text { gal/day) }\end{array}$ & $\begin{array}{l}40 \% \text { return } \\
\text { activated } \\
\text { sludge rate }\end{array}$ \\
\hline $\begin{array}{l}\text { Inflow } \\
\text { temperature, }{ }^{\circ} \mathrm{C}\end{array}$ & 11.0 & 14.3 & 13.7 & 13.0 & 12.5 \\
\hline $\begin{array}{l}\text { Inflow suspended } \\
\text { solids, mg/l }\end{array}$ & $>10 \mathrm{mg} / \mathrm{l}$ & $200 \mathrm{mg} / \mathrm{l}$ & $2000 \mathrm{mg} / \mathrm{l}$ & $200 \mathrm{mg} / \mathrm{l}$ & $2000 \mathrm{mg} / \mathrm{l}$ \\
\hline $\begin{array}{l}\text { Detention time } \\
\text { (for entire tank } \\
\text { volume), hr }\end{array}$ & 3.0 & 11.0 & 14.1 & 5.3 & 17.0 \\
\hline $\begin{array}{l}\text { Sludge layer } \\
\text { thickness, } \mathrm{m}(\mathrm{ft})\end{array}$ & $0(0)$ & $0.54(1.8)$ & $1.0(3.3)$ & $0.54(1.8)$ & $1.0(3.3)$ \\
\hline $\begin{array}{l}\text { Effective } \\
\text { Detention time } \\
\text { hr }\end{array}$ & 3.0 & 9.3 & 10.6 & 4.6 & 13.4 \\
\hline
\end{tabular}

* This is the approximate detention time of the liquid computed by subtracting the volume of the measured sludge layer from the total tank volume. 
On-site meteorological data (air temperature, relative humidity, barometric pressure, solar radiation, wind direction and speed) were measured to calculate the surface heat flux in the tanks. Suspended solids measurements were also made of the inflow and at locations throughout the tank for the secondary clarifier at the Bend treatment plant. Details of this procedure were discussed in LaLiberte (1990).

\section{Experimental Results}

\section{Temperature measurements}

The inflow to the clarifier could be distinguished from the colder ambient water by using temperature as a tracer. The inlet baffle for each tank caused the inflows to enter initially as a radial submerged buoyant jet.

Experimental data indicated that surface heat loss between the tank inlet and outlet caused temperature losses ranging from $0.5^{\circ} \mathrm{C}$ to $1.2^{\circ} \mathrm{C}$. The inlet tank water temperature varied from $11^{\circ} \mathrm{C}$ to $14.3^{\circ} \mathrm{C}$, while the equilibrium temperature (see Appendix $\mathrm{A}$ ) varied from $-7^{\circ} \mathrm{C}$ to $-32^{\circ} \mathrm{C}$ during the study periods. Evidence of thermal inversions was found during each study period.

The first study was performed on the primary clarifier in Bend on $1 / 21 / 89$. Well-mixed vertical conditions were typical for much of the study period since most water temperatures ranged between $14.6^{\circ} \mathrm{C}$ and $14.2^{\circ} \mathrm{C}$. For about 1.5 hours of the 2 hour study period, temperatures at a depth of $2.3 \mathrm{~m}$ and at a radial distance of $7.6 \mathrm{~m}$ were consistently about $0.5^{\circ} \mathrm{C}$ greater than in other areas of the tank.

For the secondary clarifier on $1 / 22 / 89$, water temperatures varied from $13.6^{\circ} \mathrm{C}$ to $12.9^{\circ} \mathrm{C}$. Again the probe at a depth of $2.3 \mathrm{~m}$ and a radial distance of $7.6 \mathrm{~m}$ indicated warmer temperatures than all the other probes by approximately $1^{\circ} \mathrm{C}$. In order to obtain more information about temperature inversions, the bottom temperature probes were set at a depth of $2.7 \mathrm{~m}$ during the next set of studies at Bend.

At Bend on 3/4/89 and 3/5/89 in both the primary and secondary clarifiers, a characteristic warmer inflow moving along the tank bottom and rising in the middle of the tank was observed. Figure 3 shows temperature as a function of depth and radial position at 5:20 am on $3 / 4 / 89$ for the primary clarifier. These data illustrate that the warm inflow rose after the initial momentum decayed and the suspended solids of about $200 \mathrm{mg} / \mathrm{l} \mathrm{settled.} \mathrm{The}$ point around $9 \mathrm{~m}$ from the center of the tank may indicate a stagnation point where downwelled, cooler, surface water meets the inflow.

This phenomenon was more clearly observed during the 3/5/89 study on the Bend secondary clarifier, where overflow rates were less and suspended solids were higher (inflow suspended solids were about $2000 \mathrm{mg} / \mathrm{l}$ ) than in the primary clarifier. Figure 4 shows the temperature regime in the tank at 2:46 am . 
These data show that the inflow temperature was often warmer than that of the water on the tank surface. The inlet baffle caused the inflow to enter as a density underflow. The buoyancy of the inflow became more dominant as solids settled and momentum diminished. Figures 5 and 6 demonstrate clearly the warmer bottom temperatures and cooler surface temperatures by comparing temperature as a function of time and radial position at depths of $0.1 \mathrm{~m}$ and $0.9 \mathrm{~m}$, respectively. The temperatures were always warmest at the radial position of $7.6 \mathrm{~m}$, and coolest near the outer walls of the tank. Apparently the inflow rises near the $7.6 \mathrm{~m}$ radial position and then cools along the surface as it moves outward toward the perimeter. The cool surface water seemed to plunge near the outer wall since vertical temperatures near that boundary were of the same magnitude as the surface temperatures.

Suspended solids grab samples were also measured during this time throughout the tank and are shown in Figure 7. The suspended solids data may indicate an area of scour in the region at about $10 \mathrm{~m}$ from the center of the tank as a result of downwelled surface water or the rake arm motion. Even the flow field is difficult to interpret from the suspended solids data, these data may also suggest that the inflow upwelled around 7-8 $\mathrm{m}$ from the center of the tank.

The study at Lake Oswego was performed between 2/3/89 and 2/7/89. The flow rate and the air temperature during this period are shown in Figure 8. The coolest air temperatures coupled with the lowest flow rates resulted in the greatest cooling potential. Figures 9, 10 and 11 show temperature data from the Lake Oswego treatment plant's radial chlorine contact chamber at radial distances of $1.5 \mathrm{~m}, 2.4 \mathrm{~m}$, and $10 \mathrm{~m}$ from the center of the tank, respectively. This tank had the highest overflow rates and hence the greatest inflow turbulence. Hence, the inflows often produced vertically well-mixed conditions. At the position nearest the outflow located at a radial distance of $10 \mathrm{~m}$, a similar pattern of warm water at the bottom and cooler water at the surface was seen. Though temperatures in the bottom layer were generally $1^{\circ} \mathrm{C}$ warmer than those in the surface layer, this did not occur at all times.

\section{Heat flux calculations}

Using measured meteorological data, the net surface heat flux was computed during each study. Details of the calculation technique are shown in Appendix A.

A hydraulic parameter that characterizes the hydrodynamic regime during winter cooling is the Richardson Flux number, $\mathfrak{R}_{\mathrm{f}}$ (Turner, 1974). This number is a ratio of the turbulent energy absorbed by buoyancy to that generated by shear. This term is defined as

$$
\Re_{f}=\frac{-\kappa \mathrm{B} h}{u_{*}^{3}}
$$

where $\kappa$ : von Karman constant $\cong 0.4$

$$
\begin{aligned}
& \text { B: buoyancy flux }=\frac{-\beta g \phi_{n}}{\rho c_{v}} \\
& \phi_{n} \text { : net surface heat flux (see Appendix A for calculation procedure) }
\end{aligned}
$$


h: surface layer depth (assumed to be the tank depth)

$\mathrm{u} *$ : shear velocity $=U\left(\frac{f_{o}}{8}\right)^{1 / 2}$

$U$ : average fluid velocity $=Q / A_{c}$ (for this study with radial flow, $A_{c}$ was the radial cross-sectional area approximated at the midpoint of the tank between the inlet baffle and the outer wall)

$f_{0}$ : Darcy-Weisbach bottom friction factor $\cong 0.01$

$\mathrm{C}_{\mathrm{v}}$ : specific heat of water at constant volume $\cong 4.186 \mathrm{~J} / \mathrm{g} / \mathrm{C}$

$\beta$ : coefficient of thermal expansion of water $\cong 10^{-4}{ }^{\circ} \mathrm{C}^{-1}$

g: acceleration due to gravity $\cong 981 \mathrm{~cm} / \mathrm{s}^{2}$

$\rho$ : density of water $\cong 0.9997 \mathrm{~g} / \mathrm{cm}^{3}$ at $10^{\circ} \mathrm{C}$

For $\Re_{f}<0$, buoyancy or surface cooling augmented the turbulence in the tank. Whenever $\Re_{f}$ $<<-1$, turbulence from surface cooling dominated turbulent production. The approximate turbulent velocity scale, $u$, associated with this convective mixing, assuming that the production rate of turbulence by buoyancy is $B$ and this is balanced by the dissipation of turbulence, $u_{t}^{3} / h$ (Turner, 1974), could be estimated as

$$
u_{t} \approx(\mathrm{B} h)^{1 / 3}
$$

In a radial tank, the magnitude of the inflow velocity decreases rapidly from the inlet baffle to the tank perimeter. Hence, the turbulence induced by the inflow and boundary shear has less and less importance away from the inlet baffle. If the order of magnitude of thermally induced vertical mixing is greater than the overflow rate (representative of the critical sedimentation velocity of a particle), particle sedimentation could be significantly affected.

Table 3 provides a summary of the recorded meteorological data and calculated hydraulic parameters for the 5 study periods. The large negative value of the net surface heat fluxes indicated that considerable heat loss occurred during the study periods. These data demonstrated that turbulence induced by surface cooling was the predominant source of turbulence in the tank. Because $\Re_{\mathrm{f}}$ was $<-1$, the turbulent velocity scale, $u_{\mathrm{t}}$, was appropriate for estimating the magnitude of the convective vertical mixing induced by surface cooling. Since $u_{t}$ was about two orders of magnitude greater than the overflow rate, $\mathrm{Q} / \mathrm{A}$, particle sedimentation may be significantly inhibited for those particles with settling velocities of magnitude $u_{t}$ or less. The magnitude of the vertical velocity scales was of order $6 \times 10^{-3} \mathrm{~m} / \mathrm{s}(520 \mathrm{~m} / \mathrm{d})$. This vertical velocity corresponds to the settling velocity of a 150 $\mu \mathrm{m}$ diameter particle or floc with a density of $1.5 \mathrm{~g} / \mathrm{cm}^{3}$. Hence, sedimentation of particle sizes less than $150 \mu \mathrm{m}$ could be affected by convective currents. 
Table 3. Summary of meteorological data and computed parameters.

\begin{tabular}{|l|l|l|l|l|l|}
\hline Parameter & $\begin{array}{l}\text { Oswego } \\
\text { chlorine } \\
\text { contact, } \\
2 / 3-7 / 89\end{array}$ & $\begin{array}{l}\text { Bend } \\
\text { primary } \\
\text { clarifier, } \\
1 / 21 / 89\end{array}$ & $\begin{array}{l}\text { Bend } \\
\text { secondary } \\
\text { clarifier, } \\
1 / 22 / 89\end{array}$ & $\begin{array}{l}\text { Bend } \\
\text { primary } \\
\text { clarifier, } \\
3 / 4 / 89\end{array}$ & $\begin{array}{l}\text { Bend } \\
\text { secondary } \\
\text { clarifier, } \\
3 / 5 / 89\end{array}$ \\
\hline \hline $\begin{array}{l}\text { Air temperature, } \\
{ }^{\circ} \mathrm{C}\end{array}$ & -9.7 & 2.8 & -2.2 & -7.2 & 2.8 \\
\hline $\begin{array}{l}\mathrm{W}_{2}, \text { wind speed, } \\
\mathrm{m} / \mathrm{s}\end{array}$ & 0.2 & 0 & 1.3 & 0 & 1.1 \\
\hline $\begin{array}{l}\text { Relative } \\
\text { humidity, \% }\end{array}$ & 60 & 100 & 50 & 90 & 90 \\
\hline Cloud Cover, \% & 10 & 80 & 90 & 70 & 80 \\
\hline $\begin{array}{l}\text { Atmospheric } \\
\text { pressure, mb }\end{array}$ & 1034 & 958 & 958 & 958 & 958 \\
\hline $\begin{array}{l}\text { Equilibrium } \\
\text { temperature, }{ }^{\circ} \mathrm{C}\end{array}$ & -32.4 & -12.7 & -11.1 & -28.2 & -6.7 \\
\hline $\mathrm{U}_{*}, \mathrm{~m} / \mathrm{s}$ & $9.0 \times 10^{-5}$ & $1.5 \times 10^{-5}$ & $1.9 \times 10^{-5}$ & $3.0 \times 10^{-5}$ & $1.5 \times 10^{-5}$ \\
\hline $\begin{array}{l}\varphi_{\mathrm{n}}, \text { net heat flux, } \\
\mathrm{W} / \mathrm{m}^{2}\end{array}$ & -384 & -220 & -394 & -351 & -241 \\
\hline $\begin{array}{l}\mathrm{B}, \text { buoyancy flux, } \\
\mathrm{m}^{2} / \mathrm{s}^{3}\end{array}$ & $9.0 \times 10^{-8}$ & $5.2 \times 10^{-8}$ & $9.2 \times 10^{-8}$ & $8.2 \times 10^{-8}$ & $5.7 \times 10^{-8}$ \\
\hline $\begin{array}{l}\Re_{\mathrm{f}}, \text { Richardson } \\
\text { flux number }\end{array}$ & $-1.3 \times 10^{5}$ & $-2.0 \times 10^{7}$ & $-1.9 \times 10^{7}$ & $-3.9 \times 10^{6}$ & $-2.3 \times 10^{7}$ \\
\hline \begin{tabular}{l}
$\mathrm{U}_{\mathrm{t}}, \mathrm{m} / \mathrm{s}$ (m/d) \\
\hline
\end{tabular} & $\begin{array}{l}6.2 \times 10^{-3} \\
(540)\end{array}$ & $\begin{array}{l}5.5 \times 10^{-3} \\
(470)\end{array}$ & $\begin{array}{l}6.9 \times 10^{-3} \\
(590)\end{array}$ & $\begin{array}{l}6.4 \times 10^{-3} \\
(550)\end{array}$ & $\begin{array}{l}5.8 \times 10^{-3} \\
(500)\end{array}$ \\
\hline
\end{tabular}




\section{Summary and Conclusions}

Temperature data from this study indicated that ideal, uniform flow often does not occur in sedimentation tanks when subject to winter cooling. The degree of non-uniformity is a complex function of inflow conditions (temperature, suspended solids, flow rate, tank geometry, and inlet baffle design) and meteorological conditions. Hence, design approaches for sedimentation tanks should consider how inflow conditions and meteorological conditions impact tank hydraulics. This impact can be evaluated by the use of flow models that account for these processes. Hydrodynamic models of these processes generally neglect the impact of turbulence produced by convective currents. For example, DeVantier and Larock (1987) neglected the effect of buoyancy production on turbulence in the tank because of computational limitations and because the effect of buoyancy on tank hydrodynamics was considered of secondary importance. McCorquodale (1997) showed that currently available models of these processes account for the impact of the inlet baffle on tank hydrodynamics, but do not account for the impact of atmospheric heating or cooling.

In uncovered clarifiers subject to significant winter cooling, vertical convective currents induced by surface cooling have the potential to hinder the settling of suspended solids.

Specific conclusions of this study were:

- the inlet baffle controlled the hydraulics of the dense underflow by forcing the inflow initially to follow the tank bottom and later to rise because of buoyancy effects

- temperature inversions in uncovered circular tanks of $1^{\circ} \mathrm{C}$ were common during the study periods

- in the early morning hours before dawn in the winter, conditions for significant temperature losses were greatest because inflow rates were lowest and cooling rates were highest

- particle sedimentation may have been inhibited by vertical convective circulation patterns in the tanks during periods of low flow and high heat loss since calculated vertical velocities were about 2 orders of magnitude greater than tank overflow rates.

\section{Acknowledgments}

Credits. The authors acknowledge the support of the personnel at the Tyron Creek Wastewater Treatment Plant and at the City of Bend Wastewater Control Plants. Brad Baird and John Harris of Portland State University were responsible for much of the data gathering and computer support. Appreciation is also expressed to a Faculty Development grant from Portland State University which provided resources to conduct this study.

Authors. Scott Wells is a Professor of Civil Engineering, Portland State University, P. O. Box 751, Portland, OR 97207-0751, (503)725-4276 FAX (503)725-4298 e-mail: scott@eas.pdx.edu . David LaLiberte was a Graduate Research Assistant at Portland State University and is now an Environmental Engineer at Montgomery-Watson, Inc., 1800 S.W. First Ave, Suite 350, Portland, OR 97201.

\section{References}


Abdel-Gawad, S. M. and McCorquodale, J. A. (1984) "Hydrodynamics of Circular Canadian J. Civil Engr. ,11, 299-307.

DeVantier, B. A. and Larock, B. E. (1987) "Modeling Sediment-Induced Density Currents in Sedimentation Basins, “ J. Hydr. Engr., ASCE, 113(1), 80-94.

Dick, R. I. (1982) "Sedimentation Since Camp," J Society of Civil Engrs, 68, 199235.

LaLiberte, D. M. (1990) "Density Currents in Circular Wastewater Treatment Tanks," M. S. Thesis, Department of Civil Engineering, Portland State University, Portland, Oregon. McCorquodale, J. A. (1997) "Mathematical Modeling of Settling Tanks," Proceedings American Filtration and Separations Society, $6^{\text {th }}$ Education Conference, Houston, TX, S21-S216.

Ryan, P. J. ; Harleman, D.R.F.; and Stolzenbach, K. D. (1974) "Surface Heat Loss Water Resources Research, 10(5), 930-938.

Tay, A. J. and Heinke, G. W. (1983) "Velocity and Suspended Solids Distribution in J. Water Pollution Control Fed., 55, 261-269. N.Y.

Turner, J. S. (1973) Buoyancy Effects in Fluids, Cambridge Univ. Press, New York,

Wells, S. A. (1990) "Effect of Winter Heat Loss on Treatment Plant Efficiency," J. Water Pollution Control Fed., 26(1),34-39. 


\section{Appendix A. Surface Heat Flux Calculations}

The following equation from Ryan et al. (1974) was used to compute the net surface heat flux, $\varphi_{n}$ :

$$
\begin{aligned}
& \varphi_{n}\left[W / m^{2}\right]=0.94 \varphi_{s c}\left(1-0.65 C^{2}\right)+5.15 \cdot 10^{-13}\left(T_{a}+273\right)^{6}\left(1+0.17 C^{2}\right)-551 \cdot 10^{-8}\left(T_{s}+273\right)^{4}- \\
& {\left[2.7\left(T_{s v}-T_{a v}\right)^{1 / 3}+3.2 W_{2}\right]\left(e_{s}-e_{a}\right)\left[1+0.61 \frac{T_{s}-T_{a}}{e_{s}-e_{a}}\right]}
\end{aligned}
$$

where $\varphi_{\mathrm{sc}}$ is the clear sky solar radiation in $\mathrm{W} / \mathrm{m}^{2}$

$\mathrm{T}_{\mathrm{a}}$ is the air temperature in ${ }^{\circ} \mathrm{C}$

$\mathrm{T}_{\mathrm{s}}$ is the surface temperature in ${ }^{\circ} \mathrm{C}$

$\mathrm{e}_{\mathrm{s}}$ is the saturated vapor pressure at water surface temperature, $\mathrm{mb}$

$\mathrm{e}_{\mathrm{a}}$ is the vapor pressure of the air, $\mathrm{mb}$

$T_{s v}$ and $T_{a v}$ are the virtual surface and air temperatures, respectively, in $\operatorname{deg} \mathrm{K}$

$$
\begin{gathered}
\mathrm{T}_{\mathrm{sv}}=\frac{\left(\mathrm{T}_{\mathrm{s}}+273\right)}{\left[1-0.378\left[\frac{\mathrm{e}_{\mathrm{s}}}{\mathrm{p}}\right]\right]} \\
\left.\mathrm{T}_{\mathrm{av}}=\frac{\left(\mathrm{T}_{\mathrm{a}}+273\right)}{\left[1-0.378\left[\frac{\mathrm{e}_{\mathrm{a}}}{\mathrm{p}}\right]\right.}\right]
\end{gathered}
$$

$\mathrm{p}$ : atmospheric pressure, $\mathrm{mb}$

$\mathrm{C}$ is cloud cover fraction from 0 to 1

$\mathrm{W}_{2}$ : wind speed, $\mathrm{m} / \mathrm{s}$, measured at a height of $2 \mathrm{~m}$ above water surface

The equilibrium temperature, the theoretical temperature that the water body would reach at steady-state, was computed by solving for $T_{s}$ in the above equation when $\varphi_{n}$ was set equal to zero. 
Figures

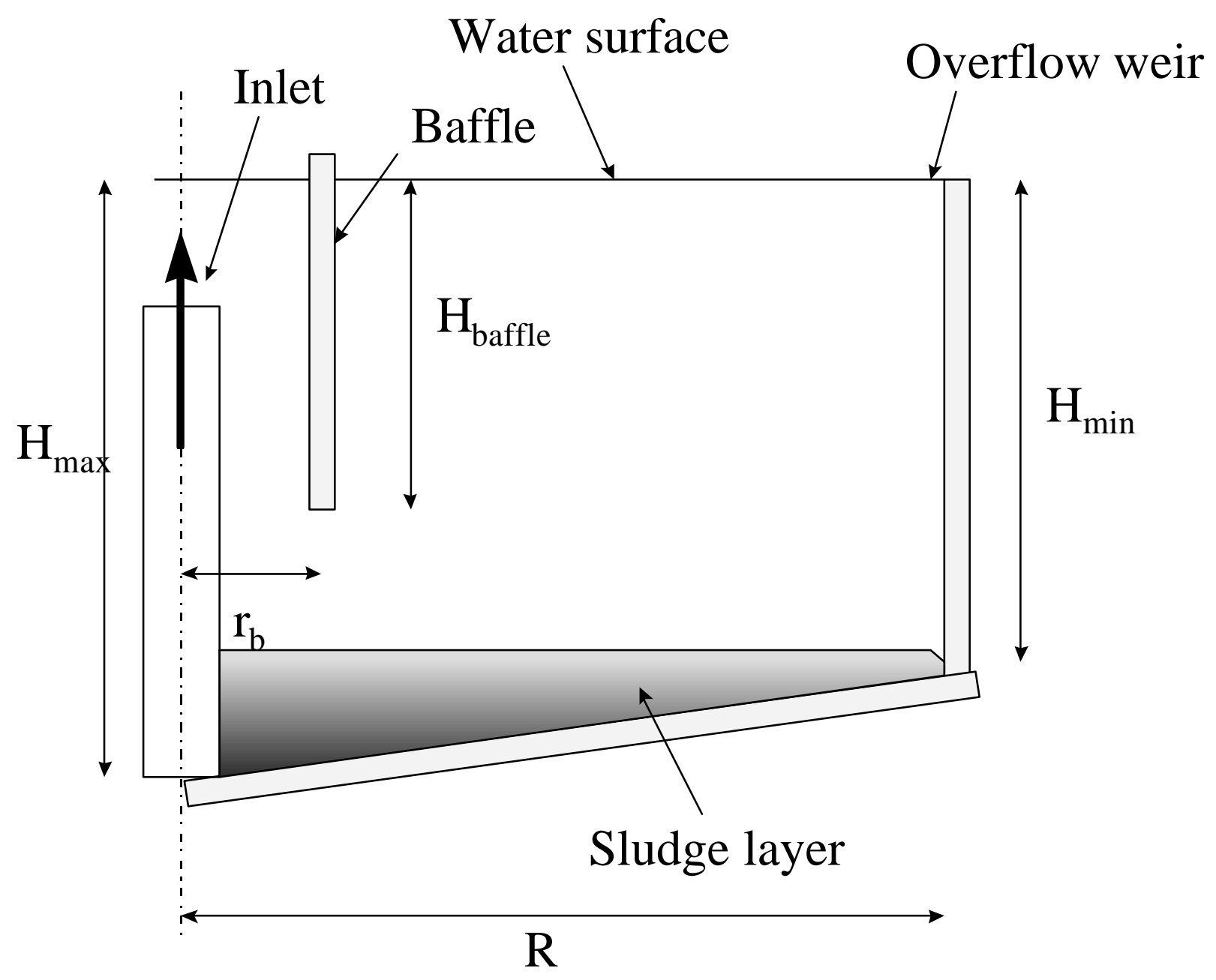

Figure 1. Schematic of circular tank. 


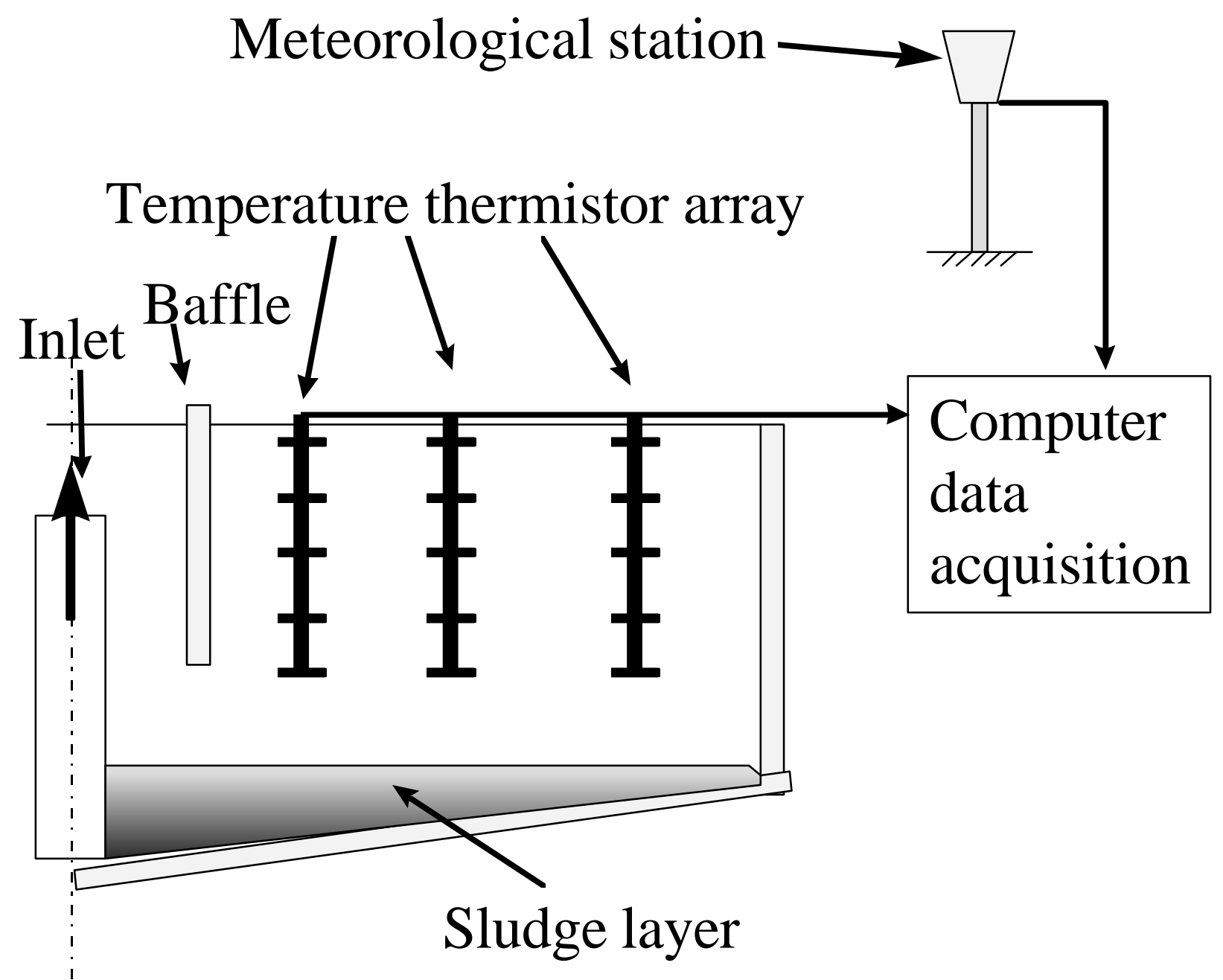

Figure 2. Location of temperature probes and computer data acquisition system for a circular tank. 


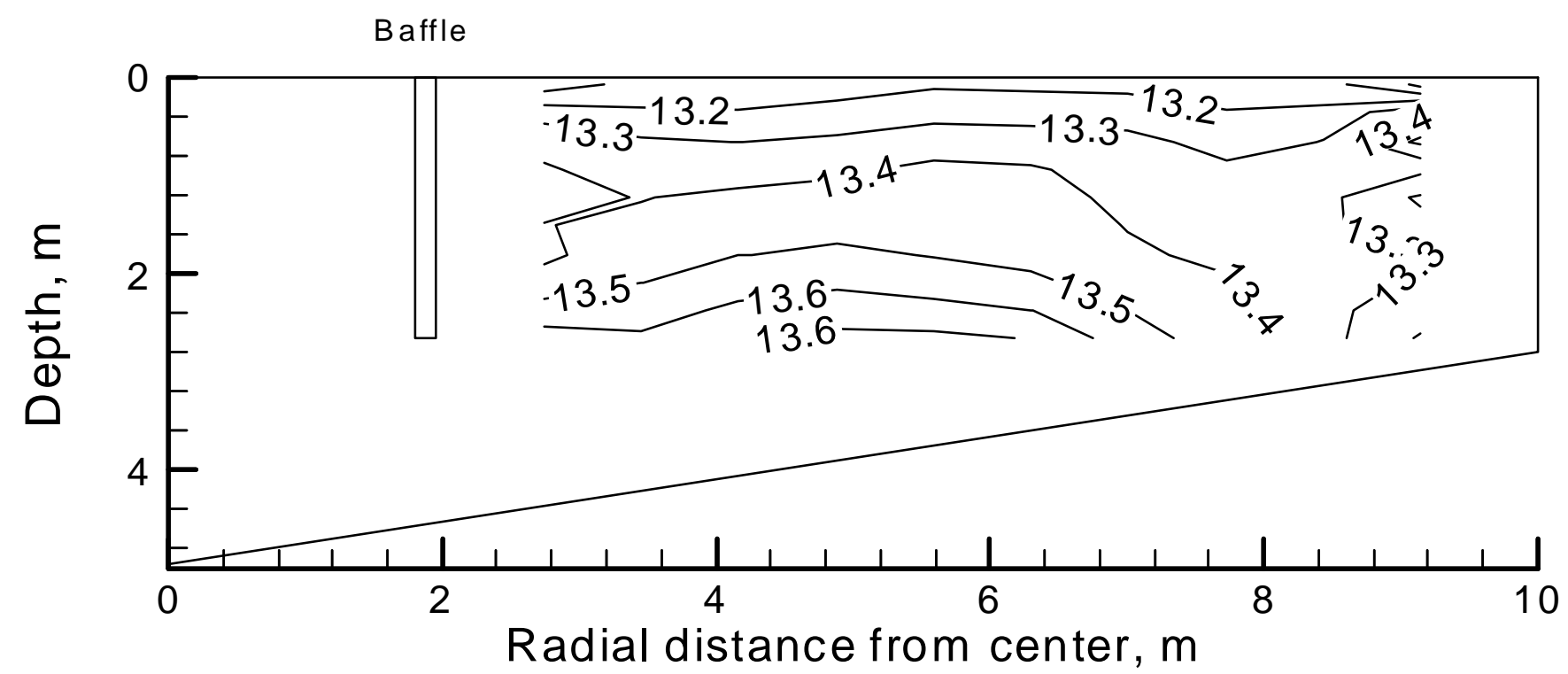

Figure 3. Temperature distribution for the Bend primary clarifier on 3/4/89 at 5:20 am. 


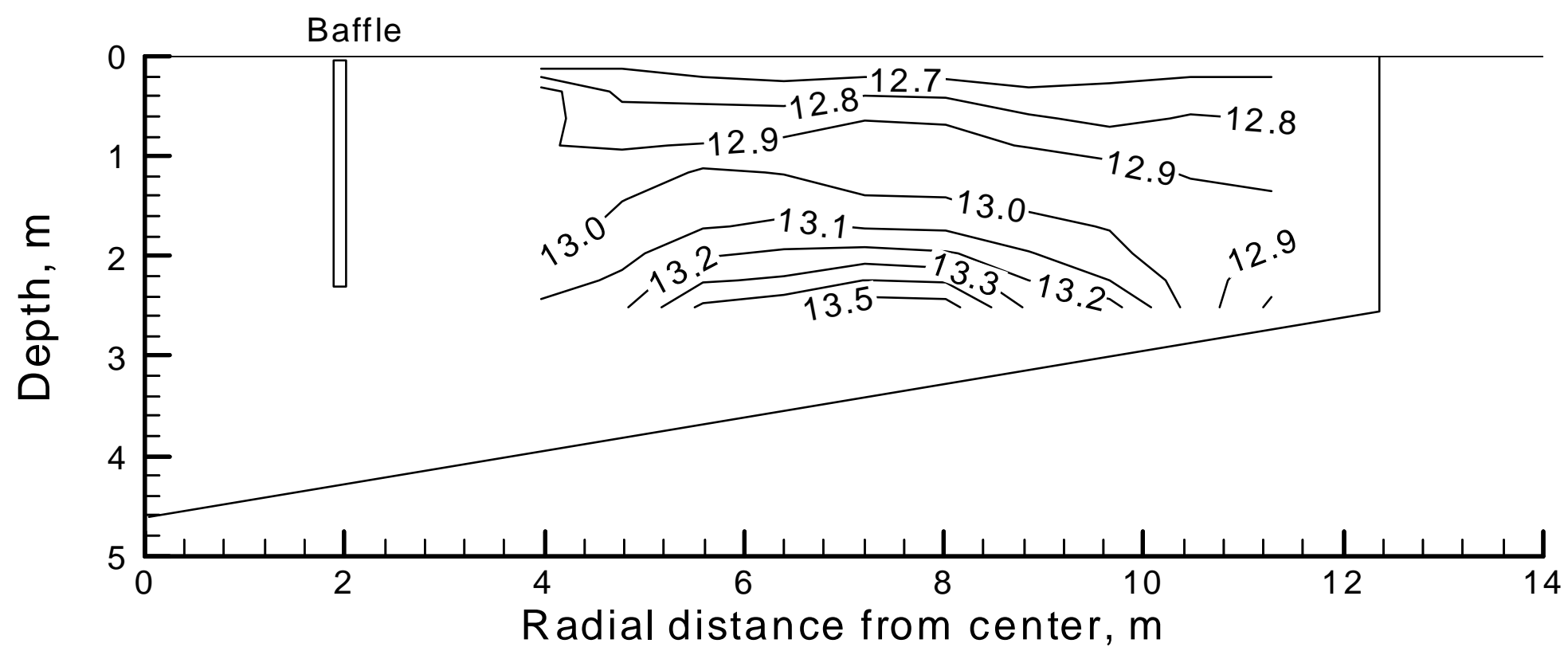

Figure 4. Temperature distribution for the Bend secondary clarifier on 3/5/89 at 2:46 am. 


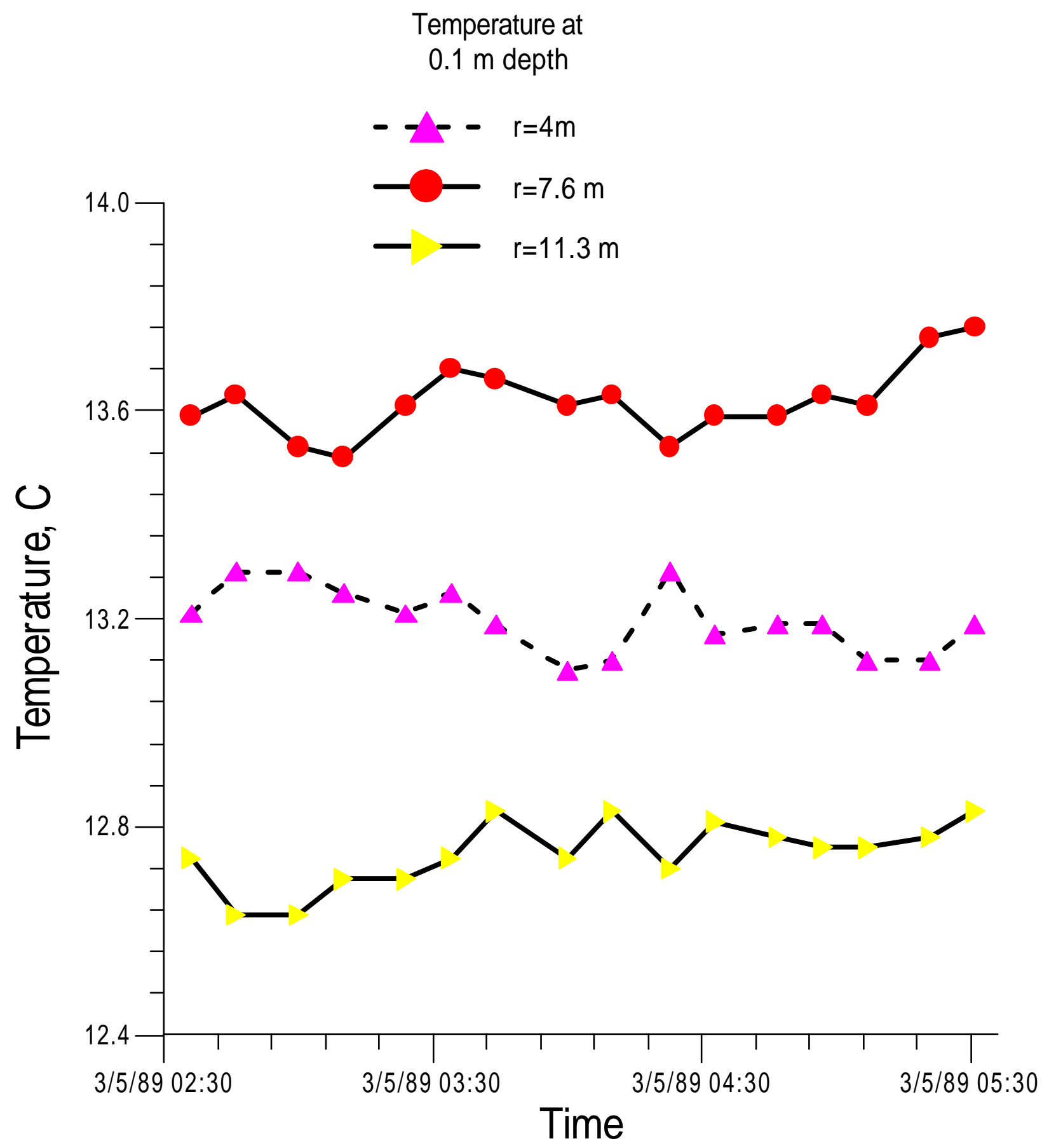

Figure 5. Temperatures for the Bend secondary clarifier on 3/5/89 near the surface at

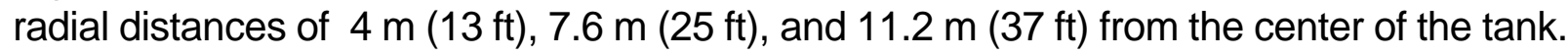




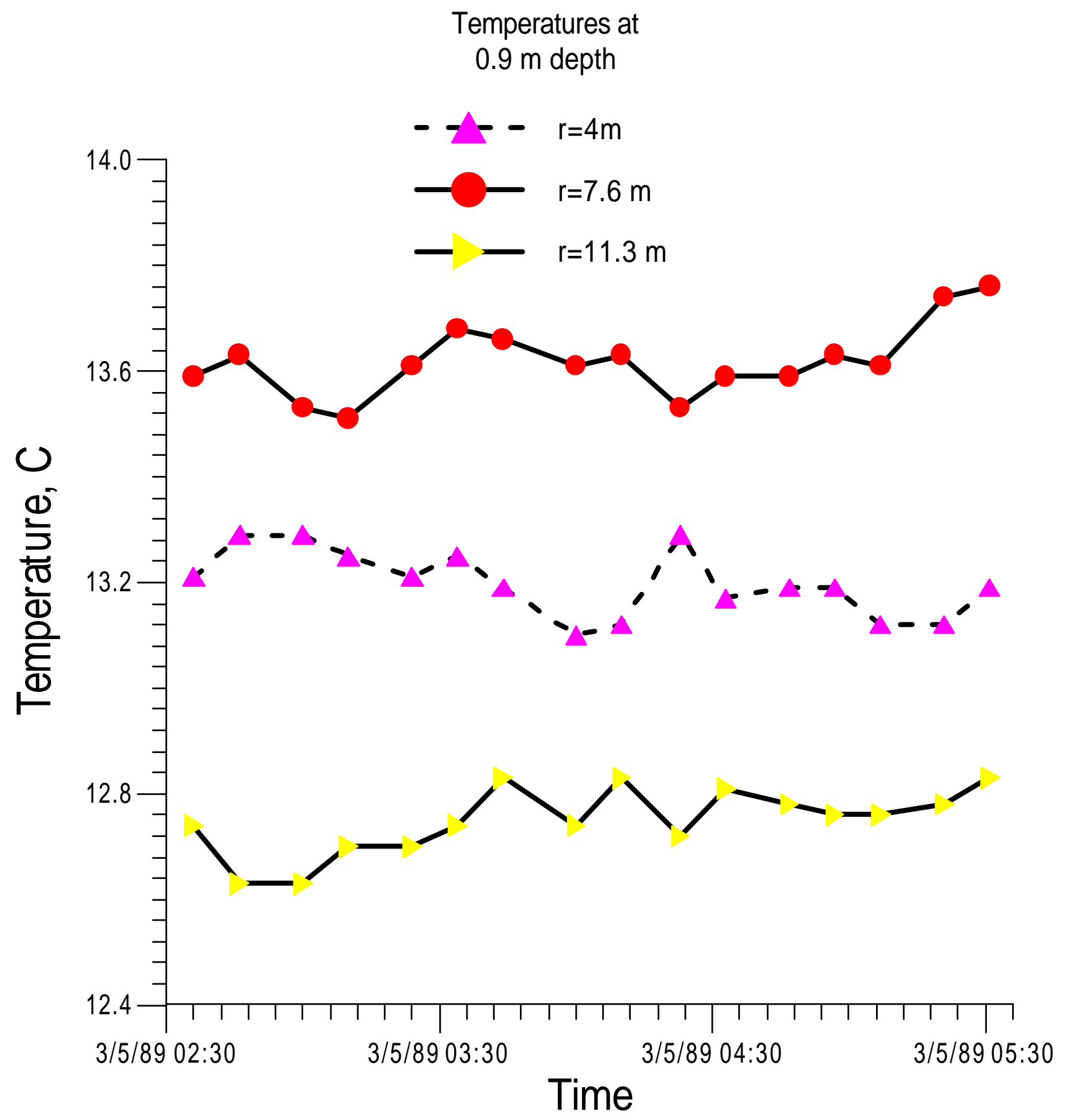

Figure 6. Temperatures for the Bend secondary clarifier on 3/5/89 $0.9 \mathrm{~m}(3 \mathrm{ft})$ below the surface at radial distances of $4 \mathrm{~m}(13 \mathrm{ft}), 7.6 \mathrm{~m}(25 \mathrm{ft})$, and $11.2 \mathrm{~m}(37 \mathrm{ft})$ from the center of the tank. 


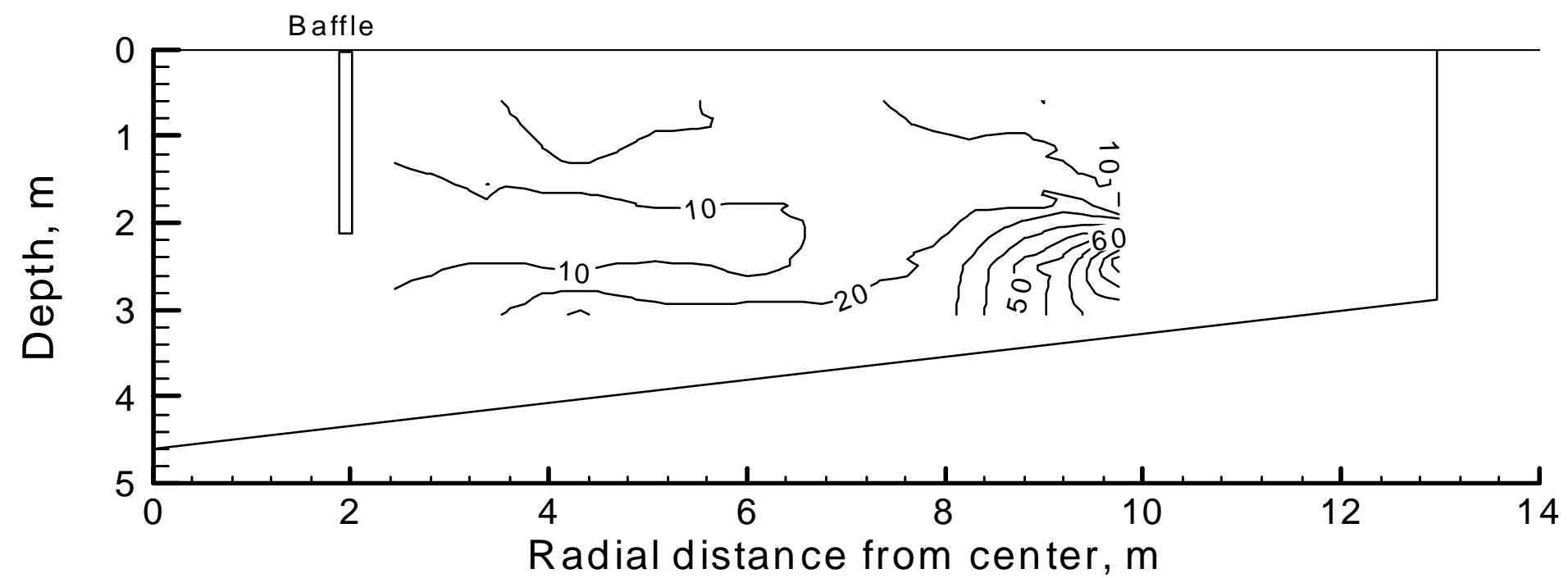

Figure 7. Suspended solids distribution for the Bend secondary clarifier between 2 am and 3 am on 3/5/89 . 


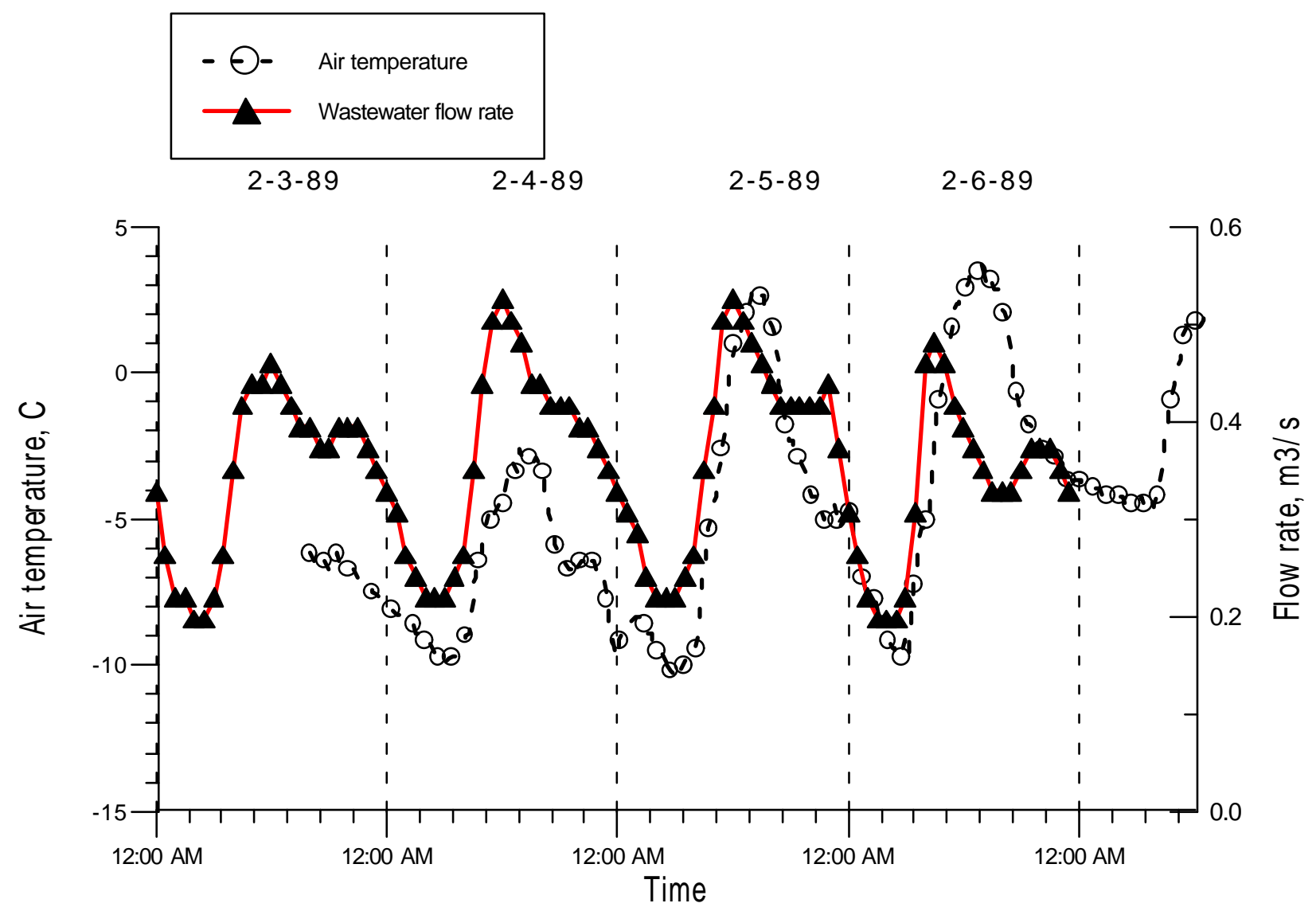

Figure 8. Flow rate and air temperature during study period for Oswego study between 2/3/89 and $2 / 7 / 89$. 


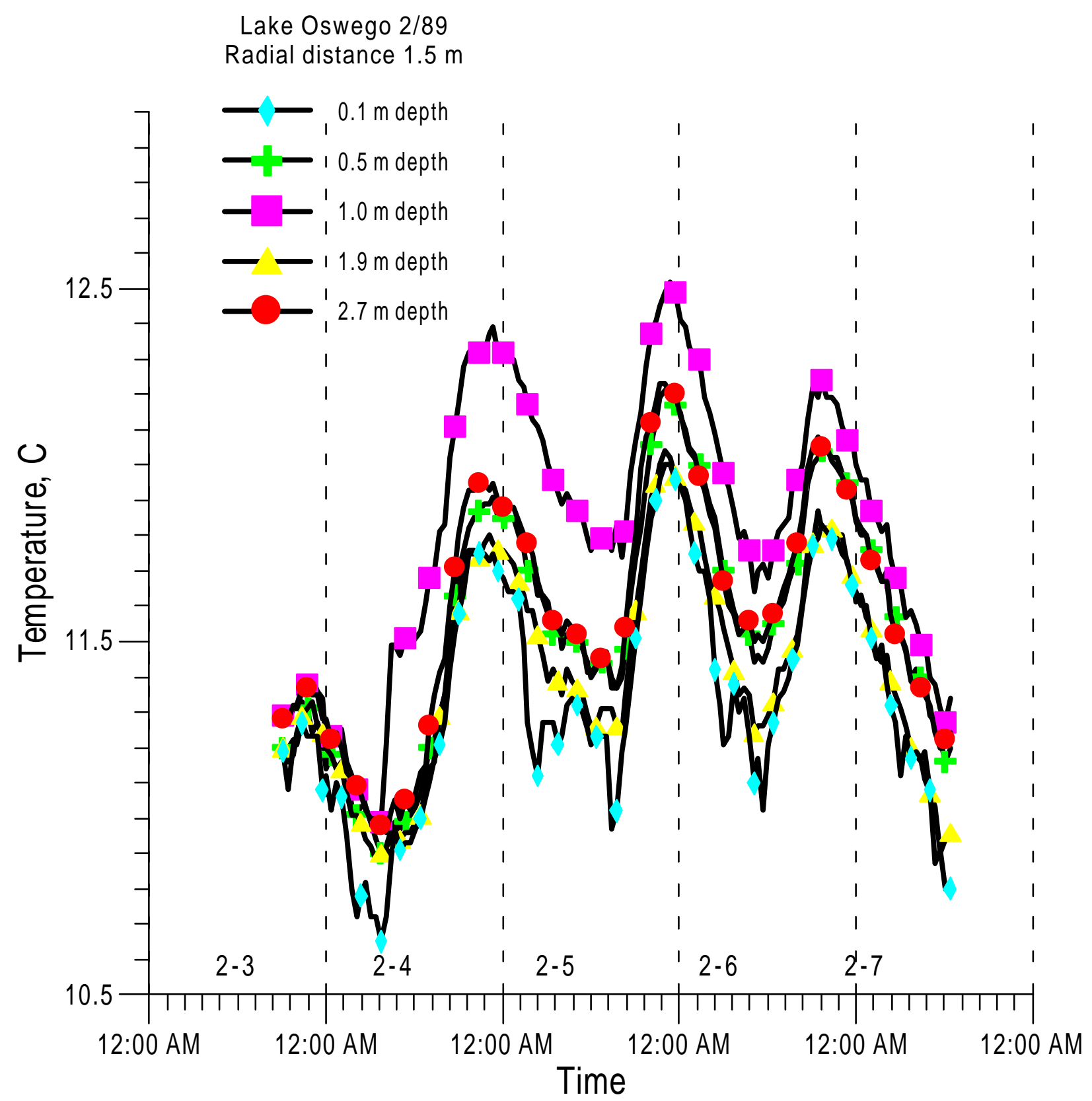

Figure 9. Vertical temperature distribution at Lake Oswego at a radial distance of $1.5 \mathrm{~m}$. 


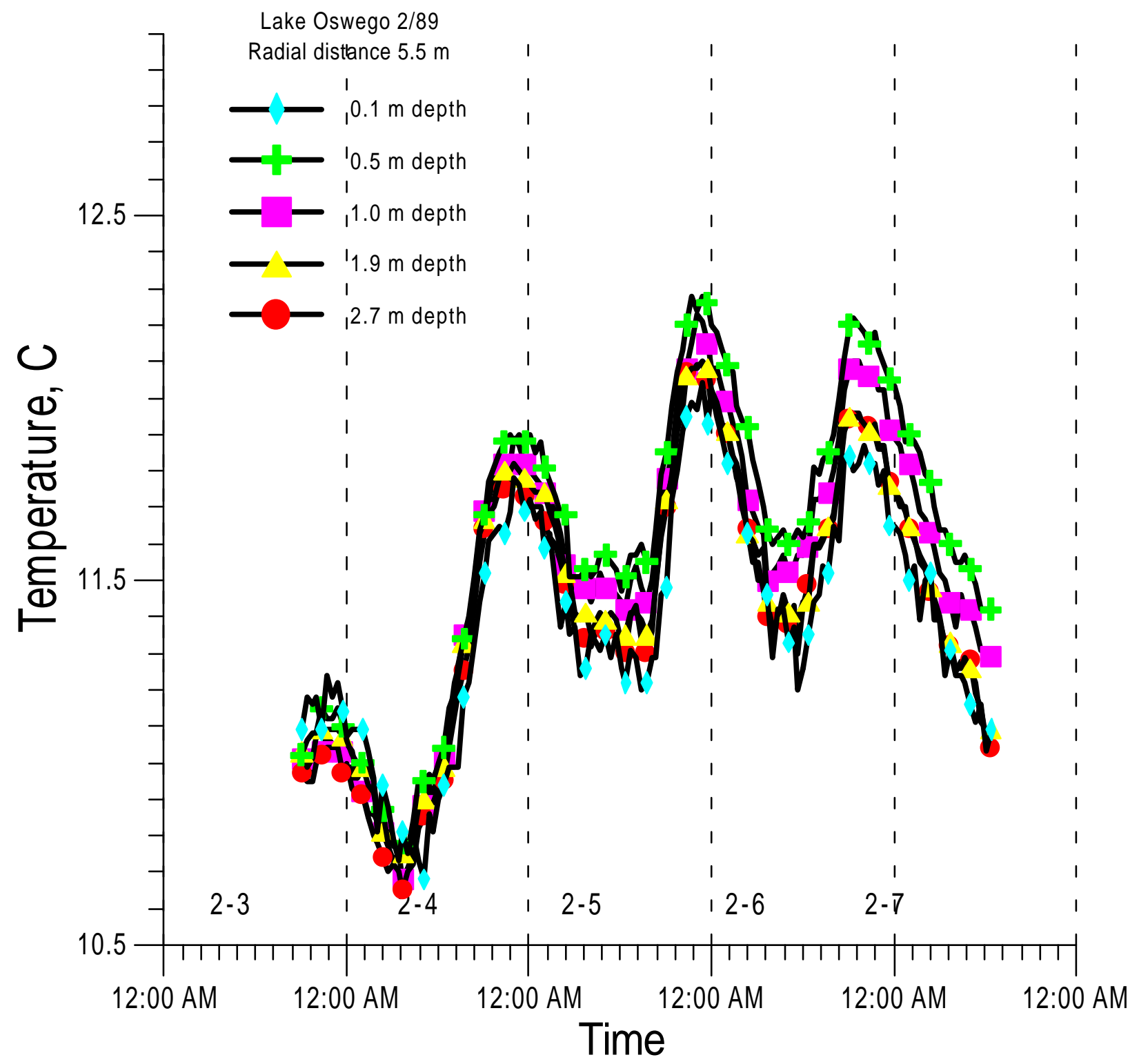

Figure 10. Vertical temperature distribution at Lake Oswego at a radial distance of $5.5 \mathrm{~m}$. 


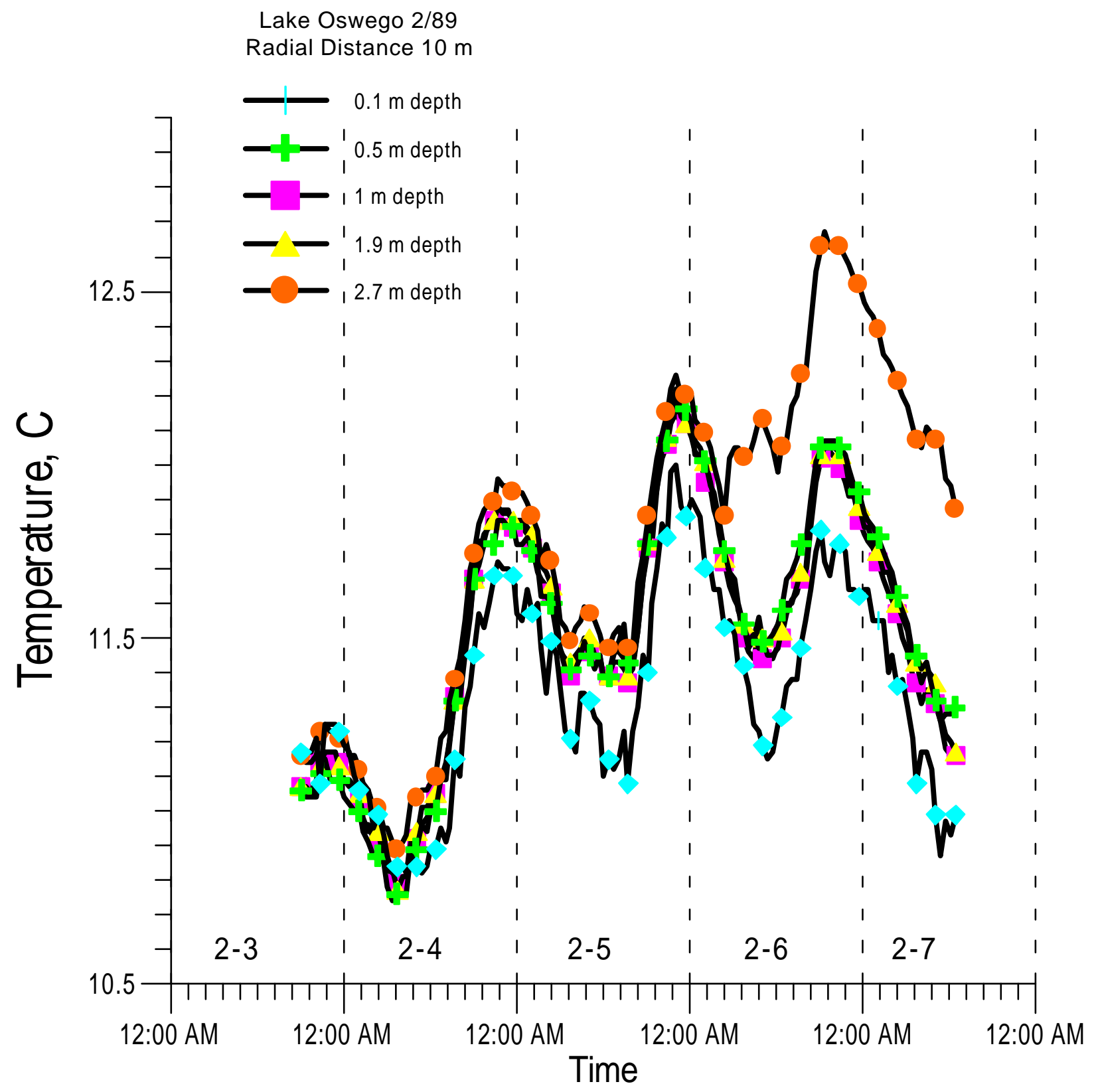

Figure 11. Vertical temperature distribution at Lake Oswego at a radial distance of $10 \mathrm{~m}$. 